\title{
Levamisole in treatment of urethane-induced pulmonary carcinoma in rats
}

\author{
Levamisol no tratamento de carcinoma pulmonar induzido por uretano \\ em ratos
}

André Luiz Costa e Silva ${ }^{1}$, Lívia Medeiros Soares Celani ${ }^{2}$, Ítalo Medeiros Azevedo ${ }^{3}$, Aldo Cunha Medeiros ${ }^{4}$

1. Graduate student, Medical School, Federal University of Rio Grande do Norte (UFRN), Natal-RN, Brazil.

2. Fellow Master degree, Postgraduate Program in Health Sciences, UFRN, Natal- RN, Brazil

3. Fellow PhD degree, Postgraduate Program in Health Sciences, UFRN, Natal- RN, Brazil

4. PhD, Full Professor, Chairman, Nucleus of Experimental Surgery, UFRN, Natal-RN, Brazil.

Research performed at the Surgery Department of the Federal University of Rio Grande do Norte (UFRN), Brazil. Scientific Initiation Program.

Financial Support: CNPq.

Conflict of interest: None.

Mailing Adress: Surgery Department, Federal University of Rio Grande do Norte, Av. Nilo Peçanha 620, Natal, RN, Brazil. E-mail: cirurgex.ufrn@gmail.com

Submitted: september 15; accepted after revision, september 23, 2019.

\section{ABSTRACT}

Objective: The potential antitumor effects of the levamisole immunomodulatory agent remain uncertain, and its beneficial effects with increased survival in the adjuvant treatment of malignant tumors are controversial. The present study aims to compare the effects of levamisole with cisplatin in the treatment of urethane-induced lung carcinoma in rats. Methods: Wistar rats were allocated into three groups ( $n=$ six each). Group A: mice with lung tumor + treatment with levamisole. Group B: mice with lung tumor + cisplatin treatment. Group C: mice with lung tumor + saline treatment. After 12 weeks of the tumor induction process, the results were validated by ex vivo fluorescence imaging, determining the mean fluorescent intensity in the animal's lungs. Serum dosages of cytokines and alkaline phosphatase were performed. Results: Mean fluorescence intensity (MFI) in the lungs (ex vivo) was measured in all animals subjected to urethane effects. In levamisole-treated, the intensity $(245+/-15)$ was lower than in cisplatin-treated $(277+/-28)$, but the difference was not statistically significant $(p<0.05)$. 
In those treated with saline, the MFI was $680+/-57$, significantly higher than in the other groups $(p<0.05)$. Dosages of TNF- $\alpha(\mathrm{pg} / \mathrm{ml}), I L-I \beta(\mathrm{pg} / \mathrm{ml}), I L-6(\mathrm{pg} / \mathrm{ml})$ and alkaline phosphatase $(\mathrm{mg} / \mathrm{dl})$ were significantly lower in levamisole-treated rats than in rats with cisplatin and saline $(p<0.005)$. Conclusion: In conclusion, this study demonstrates the positive influence of levamisole in treatment of urethane-induced lung tumors in rats.

Keywords: Lung carcinoma. Carcinogenesis. Urethane. Treatment. Levamisole. Cisplatin. Rats

\section{RESUMO}

Objetivo: Os potenciais efeitos antitumorais do agente imunomodulador levamisol permanecem incertos, e seus efeitos benéficos com aumento da sobrevida com tratamento adjuvante dos tumores malignos é controverso. $O$ presente estudo tem 0 objetivo de comparar os efeitos do levamisol com os da cisplatina no tratamento do carcinoma de pulmão induzido pelo agente carcinogênico uretano, em ratos. Métodos: Ratos Wistar foram alocados em 3 grupos ( $n=6$ cada). Grupo A: ratos com tumor de pulmão + tratamento com levamisol. Grupo B: ratos com tumor de pulmão + tratamento com cisplatina. Grupo C: ratos com tumor de pulmão + tratamento com solução salina. Após 12 semanas do processo de indução dos tumores, a validação dos resultados foi aferida através de exames de imagem de fluorescência ex-vivo, determinando a intensidade fluorescente média nos pulmões dos animais. Dosagens séricas de citocinas e fosfatase alcalina foram realizadas. Resultados: A intensidade média da fluorescência (IMF) nos pulmões (ex-vivo) foi medida em todos os animais submetidos aos efeitos do uretano. Nos tratados com levamisol a intensidade $(245 \pm 15)$ foi menor do que nos tratados com cisplatina $(277 \pm 28)$, porém a diferença não foi estatisticamente significante $(p>0,05)$. Nos tratados com solução salina a IMF foi de $680 \pm 57$, significativamente mais elevada do que nos demais grupos $(p<0,05)$. As dosagens de TNF- $\alpha(\mathrm{pg} / \mathrm{ml}), \mathrm{IL}-\mathrm{I} \beta(\mathrm{pg} / \mathrm{ml})$, IL-6 (pg/ml) e fosfatase alcalina ( $\mathrm{mg} / \mathrm{dl})$ foram significativamente mais reduzidas nos ratos tratados com levamisol do que nos tratados com cisplatina e solução salina $(p<0,05)$. Conclusão: Em conclusão, este estudo demonstra claramente a influência positiva do levamisol no tratamento de tumores de pulmão induzidos por uretano em ratos.

Descritores: Carcinoma pulmonar. Carcinogênese. Uretano. Tratamento. Levamisol. Cisplatina. Ratos. 
Levamisole in treatment of urethane-induced pulmonary carcinoma in rats Silva $A L C$, et al

\section{INTRODUCTION}

Animal model systems have allowed significant advances in the study of carcinogenesis. Urethane is a chemical carcinogen that specifically promotes the development of lung tumors ${ }^{1}$. In vivo, urethane transforms into the intermediate vinyl carbamate epoxide compound in a reaction mediated by CYP2E1, a cytochrome P450 enzyme, which acts on the bronchiolar cells of the lung. Vinyl carbamate epoxide binds to DNA, causing genetic changes involved in the development of lung tumors ${ }^{2}$. Some male rodent strains have a higher overall sensitivity to urethane carcinogenic effects than female rodents ${ }^{3}$. It has been shown that the carcinogenic effect of urethane is twice as high in males as in females4.

Levamisole (LEV) is a synthetic imidazole-phenyl-thiazole widely used as anthelmintic and works as an immunomodulator preventing the action of suppressor $\mathrm{T}$ cells. LEV has been shown to increase delayed hypersensitivity reactions, mitogenic response and in vitro lymphocyte proliferation. It is effective in cellular immunity and stimulates T lymphocytes more than B-lymphocytes. LEV induces stronger Th1 immune responses by activating dendritic cells or inducing toll-like receptor expression5, 6. In studies conducted on animals infected with enterotoxic Escherichia coli, it has been shown that LEV influenced T cell proliferation in ileal villi by stimulating differentiation and proliferation of lymphocytes in the lamina propria and Peyer's plaques of intestinal mucosa7.

LEV can also affect $M$ cell differentiation and proliferation, increasing their number in intestinal villi. Lately, attention has been focused on $M$ cells and their interactions with Peyer's plaque immune cells, the main inductive defense sites in gut. It has been shown that stimulation of $\mathrm{M}$ cell proliferation in ileal villi may have relevance to the process of cellular immunity exerted by the intestinal lamina propria8, 9.

A large-scale clinical trial showed that adjunctive treatment of 12-month-old colon cancer with 5-fluoracil (5-FU) associated with LEV significantly improved survival compared with LEV or surgery alone10, 11. The treatment combining 5-FU + LEV was subsequently recommended as standard by the European Consensus Conference and 
the NIH. While the potential antitumor effects of the LEV immunomodulatory agent remain uncertain, its beneficial effect with the adjuvant treatment of colon tumors has been proven12. LEV has been shown to be effective in some studies and not others. However, studies in which no beneficial effects were observed, especially on survival, were related to terminal melanomas and other advanced tumors13. In the present protocol, we study the effects of LEV on the evolution of newly induced lung tumors, therefore not advanced or metastatic.

\section{OBJECTIVE}

The present Project aims to compare the effects of levamisole with cisplatin effect on the treatment of urethane-induced lung carcinoma in rats.

\section{METHODS}

Rats (Rattus norgegicus, Wistar) with an average weight of $275+/-23 g$, from the Health Sciences Center Biotery of the Federal University of Rio Grande do Norte (UFRN), Brazil, were used. This protocol was submitted to the institutional Animal Ethics Committee (CEUA) and approved by protocol 01/2018. Care in the use of animals followed the rules in force in the Brazilian Legislation for the scientific use of animals (Law No. 11794/2008). The study was conducted at the Experimental Surgery CenterUFRN.

\section{Experimental design}

The animals were randomly selected and divided into three groups, with six rats each.

Group A: lung tumor rats + treatment with levamisole.

Group B: lung tumor rats + cisplatin treatment.

Group C: lung tumor rats + saline treatment.

Rats were kept in individual polypropylene cages with 12-hour light-dark cycles, room temperature $22^{\circ} \mathrm{C}$ and particle control. Initially, the animals underwent a 7-day acclimatization period in the laboratory, with ad libitum access to water and rodent food (Presence ${ }^{\circledR}$ ).

Induction of pulmonar neoplasia 
The animals were handled in the experimental rooms of the Experimental Surgery Center-UFRN, Brazil, and during the observation period were kept in a postoperative control room. The rats were randomly distributed in the levamisole $(n=$ $6)$, cisplatin $(n=6)$ and control $(n=6)$ groups. All rats received treatment with a weekly intraperitoneal injection of $50 \mathrm{mg} / \mathrm{kg}$ urethane (Sigma Chemical Company, St. Louis, MO) for four weeks. Drug treatment started in week 6, when the onset of adenomas and neoplastic lesions was expected to begin, according to a study by Umemura et al, 199914.

\section{Animals treatment}

In the first week after the initiation of tumor induction, $25 \mathrm{mg} / \mathrm{kg}$ of levamisole (Zeneca) was injected intraperitoneally (i.p.) into group A rats, with one dose being repeated once a week. Group B animals were treated with cisplatin at a dose of $5 \mathrm{mg} / \mathrm{kg}$ i.p., single dose15.

Group C: animals were treated with saline i.p.

\section{Ex vivo imaging exams by fluorescence}

After the 12th week of neoplasia induction and treatments, the animals were anesthetized (Ketamine $70 \mathrm{mg} / \mathrm{kg}$ and Xylazine $10 \mathrm{mg} / \mathrm{kg}$ i.p.) and intravenous injection of $0.5 \mathrm{ml}$ green indocyanine ( $25 \mathrm{mg}$ diluted in $2 \mathrm{ml}$ of saline solution). After $24-$ hours a thoracotomy was performed, the lungs fully excised, washed in saline solution and wiped with sterile gauze. Fluorescence images of ex vivo lungs were obtained using the Kodak-FX Image Station. The emission and excitation filters were 700 and $540 \mathrm{~nm}$ respectively. The imaging protocol (60-second exposure time, 4x binning, f-stop 2.5, 160 $\mathrm{mm}$ field of view and $9 \mathrm{~mm}$ focal plane) was maintained for all examinations. The images were analyzed by Kodak Molecular Imaging software (version 5.0) and qualified according to a color scale. A region of interest (ROI) has been created and determined around the lungs. Average signal intensities of the region of interest were expressed as arbitrary units of fluorescent signal intensity. Fluorescence grayscale images were artificially colored for representation purposes according to a scale set for the highest and lowest levels of mean fluorescence intensity (red and purple indicated maximum and minimum light intensity, respectively). 
Levamisole in treatment of urethane-induced pulmonary carcinoma in rats

Silva ALC, et al

\section{Dosage of cytokines and alkaline phosphatase}

At the end of the observation period, under anesthesia, blood was collected by cardiac puncture to measure tumor necrosis factor-alpha (TNF-?]), interleukin-1? (IL-1] ? and interleukin-6 (IL-6). The blood remained in vials without anticoagulant for 30 minutes and the serum was separated by centrifugation at $3000 \mathrm{rpm}$ and stores at $-40^{\circ} \mathrm{C}$ for subsequent dosing. Cytokines were measured by enzyme-linked immunosorbent assay (ELISA). The reagents used were from PeproTech, USA. Alkaline phosphatase was measured on the Konelab60i automated analyzer, Kits Wiener Lab.

\section{Statistic}

Statistical evaluation was performed by analysis of variance (ANOVA) followed by Tukey test, considering significant differences when $p<0.05$. BioEstat 5.0 software was used, Belém, PA, Brazil.

\section{RESULTS}

Visual representations of changes in fluorescence signal intensity were obtained by applying a series of colors grading the fluorescence signal intensity. Quantitation of ex vivo fluorescence intensity of regions of interest of affected lungs peaked 10 hours after intravenous administration of green indocyanine, remaining up to 24 hours. The fluorescence signal was significantly higher in the lung cancer regions of urethane and saline-treated rats. Besides, the fluorescence signal was lower or absent in lung areas not affected by lung tumor. The fluorescence signal was anatomically located in the presence of the lung tumor. This demonstrates the preferential localization of green indocyanine in lung tumors (figure 1).

Levamisole Group

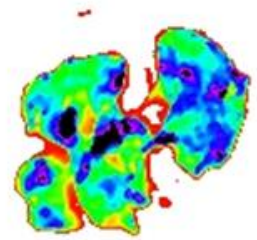

Cisplatin Group

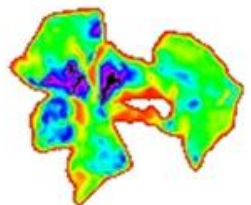

Control Group

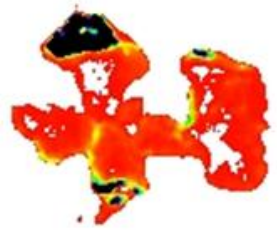

Figure 1. Representative images of the ex vivo lung fluorescence of animals of the respective groups. The lungs of levamisol and cisplatin groups exhibit rare low-intensity fluorescent red areas. In the control group, there is intense disseminated fluorescent activity in both lungs. 
Mean fluorescence intensity (MFI) in the lungs (ex vivo) was measured in all animals subjected to urethane effects. In levamisol-treated, the intensity (245 +/- 15) was lower than in cisplatin-treated $(277+/-28)$, but the difference was not statistically significant ( $p>0.05$ ). However, in those treated with saline, the MFI was $680+/-57$, significantly higher than in the other groups $(p<0.05)$. Data summarized in Table 1.

Table 1. Mean fluorescence intensity (MIF) values and their statistical interpretation.

\begin{tabular}{ccccc}
\hline Variable & Levamisole & Cisplatin & Control & P-value \\
\hline MIF & $245 \pm 15^{\mathrm{B}}$ & $277 \pm 28^{\mathrm{A}}$ & $680 \pm 57^{\mathrm{AB}}$ & $<0,05$ \\
\hline
\end{tabular}

MIF - mean fluorescence intensity. Mean +/- standard deviation. Values in the same row followed by equal letters mean statistically significant differences. Tukey test.

Dosages of TNF- $\alpha(\mathrm{pg} / \mathrm{ml}), \mathrm{IL}-\mathrm{I} \beta(\mathrm{pg} / \mathrm{ml}), \mathrm{IL}-6(\mathrm{pg} / \mathrm{ml})$ and alkaline phosphatase $(\mathrm{mg} / \mathrm{dl})$ were significantly lower in levamisol-treated rats than in rats with cisplatin and saline solution $(p<0.005)$. Data summarized in Table 2.

Table 2. Cytokine and alkaline phosphatase dosage values and their statistical interpretation.

\begin{tabular}{lcccc}
\hline \multicolumn{1}{c}{ Variable } & Levamisole & Cisplatin & Control & P-value \\
\hline TNF- $\alpha(\mathrm{pg} / \mathrm{ml})$ & $172,9 \pm 15^{\mathrm{A}}$ & $193,5 \pm 25,7^{\mathrm{B}}$ & $371,95 \pm 42,9^{\mathrm{A}, \mathrm{B}}$ & $<0,05$ \\
\hline $\mathrm{IL}-\mathrm{I}(\mathrm{pg} / \mathrm{ml})$ & $41,61 \pm 7,0^{\mathrm{A}}$ & $58,2 \pm 6,3^{\mathrm{A}}$ & $83,5 \pm 10,2^{\mathrm{A}}$ & $<0,05$ \\
\hline $\mathrm{IL}-6(\mathrm{pg} / \mathrm{ml})$ & $77,3 \pm 9,0^{\mathrm{A}}$ & $98,6 \pm 10,4^{\mathrm{A}}$ & $230,5 \pm 13,2^{\mathrm{A}}$ & $<0,01$ \\
\hline $\mathrm{AP}(\mathrm{mg} / \mathrm{dl})$ & $79,4 \pm 11,2^{\mathrm{A}}$ & $118,7 \pm 15,4^{\mathrm{A}}$ & $187,5 \pm 18,7^{\mathrm{A}}$ & $<0,01$ \\
\hline
\end{tabular}

TNF- $\alpha$, Tumor necrosis factor-alpha; IL, Interleukin; AP, Alkaline phosphatase. Mean \pm standard deviation. Values in the same row followed by equal letters mean statistically significant differences. Tukey test.

\section{DISCUSSION}

Levamisole (LMS) is an anthelmintic imidazothiazole that has been used for many years. Besides, it is effective in reducing the risk of tumor recurrence when adjunctly administered to patients with surgically resected stage III colon cancer ${ }^{10,16}$, although it is no longer used clinically in this setting. It is believed to act by stimulating the cellular immune system. In patients, LMS has been shown to increase the number of circulating NK (natural killer) cells ${ }^{17}$, the expression of CD25 (IL2 receptor) on the membrane ${ }^{18}$ and to increase serum IL-2 levels ${ }^{19}$.

Fluorescent imaging acquisition times were chosen based on the work of Ishizawa et al (2009) ${ }^{20}$, who reported that fluoresce imaging is preferably at least 24 
hours after administration of green indocyanine. As the maximum fluorescence penetration depth is up to $1 \mathrm{~cm}$, the identification of non-deeply situated lung tumors in preclinical studies is challenging. Knowing this, in our study, we performed ex vivo imaging exams. Improvements in imaging systems, new fluorescence contrast agents, more accurate software, and reduction in background fluorescence can facilitate fluorescence imaging of deeper localized tumors and metastases.

Levamisole (LMS), which is an immunostimulator, has been studied as synergistic to 5-fluorouacil in adjuvant therapy in patients with stages III colon cancer. Immunological parameters included lymphocyte antigen expression and serum cytokine levels. It has been suggested that LMS is immunomodulatory and well-tolerated. Holcombe et al (2001) observed that LMS is a potential chemopreventive agent of colon cancer $^{21}$.

Clarke et al (1997) ${ }^{22}$ examined the immunomodulatory effect of levamisol on NC-1.1 + cell-mediated natural cytotoxicity against BALB / c WEHI-164 murine fibrosarcoma. Levamisole administration to BALB / c rats significantly increased in vitro splenic natural cytotoxic against tumor cells. The effect was most pronounced 48 hours after treatment with levamisol at a dose of $10 \mathrm{mg} / \mathrm{kg}$ body weight. Levamisole (10 $\mathrm{mg} / \mathrm{kg}$ ) significantly reduced WEHI-164 fibrosarcoma growth and this effect was observed in the pretreatment of rats, indicating an antitumor effect of levamisol ${ }^{22}$. The effect of Levamisole was observed on CD138 expression and IL-6 secretion, proving once again that Levamisole is an antineoplastic drug ${ }^{23}$. Serum IL-6 levels are associated with disease activity in myeloma and elevated levels indicate severity ${ }^{24}$. Besides, IL-6 appears to have antiapoptotic activity in various $\mathrm{B}^{25}$ cell tumors. Given its effect on tumor cell growth, survival, adhesion, and invasion, IL-6 may be a potential beneficial regulator of myeloma pathobiology. Therefore, drugs that affect IL-6 function are expected to be useful as therapeutic agents in myeloma patients. In our study, we observed significant reduction in IL-6 levels in the levamisol treated group.

Levamisole has the property of inhibiting alkaline phosphatase (AP) $26,27$. Increased AP activity correlates with tumor cell proliferation. Our results showed that in levamisol-treated rats, AP levels were significantly lower than in the other groups. 
Levamisole in treatment of urethane-induced pulmonary carcinoma in rats

Silva ALC, et al

In conclusion, this study demonstrates the positive influence of levamisol in the treatment of urethane-induced lung tumor in rats.

\section{REFERENCES}

1. Pfistermuller KLM, McArdle AJ, Cuckow PM. Meta-analysis of complication rates of the tubularized incised plate (TIP) repair. J Pediatr Urol. 2015; 11: 54-9.

2. Mason R J, Kalina M, Nielsen L D, et al. Surfactant protein C expression in urethaneinduced murine pulmonary tumors. Am J Pathol. 2000;156:175-82.

3. Forkert P G. Mechanisms of lung tumorigenesis by ethyl carbamate and vinyl carbamate. Drug Metab Rev. 2010; 42: 355-78.

4. Timofeeva OA, Eremeev AV, Goloshchapov A, et al. Effects of o-aminoazotoluene on liver regeneration and p53 activation in mice susceptible and resistant to hepatocarcinogenesis. Toxicology. 2008;254:91-6.

5. Morozkova TS, Kaledin VI. Sex-related differences in the sensitivity to carcinogenic effect of urethane on the lungs in mice are reversed after neonatal androgenization. Bull Exp Biol Med. 2015;159:782-5.

6. Zhang $\mathrm{W}, \mathrm{Du} \mathrm{X}$, Zhao $\mathrm{G}$ et al. Levamisole is a potential facilitator for the activation of Th1 responses of the subunit HBV vaccination. Vaccine. 2009;27:4938-46.

7. Chen LY, Lin YL, Chiang BL. Levamisole enhances immune response by affecting the activation and maturation of human monocytederived dendritic cells. Clin Exp Immunol. 2008;151:174-81.

8. Božić F, Bilić V, Valpotić I. Levamisole mucosal adjuvant activity for a live attenuated Escherichia coli oral vaccine in weaned pigs. J Vet Pharmacol Ther. 2003; 26:225-31.

9. Valpotić $H$, Kovšca Janjatović $A$, et al. Increased number of intestinal villous $M$ cells in levamisole -pretreated weaned pigs experimentally infected with $\mathrm{F}_{4} \mathrm{ac}^{+}$ enterotoxigenic Escherichia coli strain. Eur J Histochem. 2010;54:e18, 88-91.

10. Božić $F$, Lacković $G$, Kovšca Janjatović $A$, ET AL. Levamisole synergizes experimental $\mathrm{F} 4 \mathrm{ac}+$ Escherichia coli oral vaccine in stimulating ileal Peyer's patch T cells in weaned pigs. J Vet Pharmacol Ther. 2006;29:199-204.

11. Moertel CG, Fleming TR, Macdonald JS, et al. Levamisole and fluorouracil for adjuvant therapy of resected colon carcinoma. N Engl J Med. 1990;322:352-8.

12. Van Triest B, Pinedo HM, Giaccone G, et al. Downstream molecular determinants of response to 5-fluorouracil and antifolate thymidylate synthase inhibitors. Ann Oncol. 2000;11:385-91.

13. Link KH, Kornmann M, Staib L, et al. Study Group Oncology of Gastrointestinal Tumors. Increase of survival benefit in advanced resectable colon cancer by extent of adjuvant treatment: results of a randomized trial comparing modulation of 5-FU + levamisole with folinic acid or with interferon-alpha. Ann Surg. 2005;242:178-87.

14. Creagan ET, Rowland KM Jr, Suman VJ, et al. Phase II study of combined levamisole with recombinant interleukin- 2 in patients with advanced malignant melanoma. Am J Clin Oncol. 1997;20:490-2. 
15. Umemura $\mathrm{T}$, Kodama $\mathrm{Y}$, Hioki $\mathrm{K}$, et al. Susceptibility to urethane carcinogenesis of transgenic mice carrying a human prototype c-Ha-ras gene (rasH2 mice) and its modification by butylhydroxytoluene. Cancer Lett. 1999;145:101-6.

16. Kawahara M, Takahashi Y, Takazawa K, et al. Caffeine dose-dependently potentiates the antitumor effect of cisplatin on osteosarcomas. Anticancer Res. 2008;(3A):16815.

17. Laurie JA, Moertel CG, Fleming TR, Wieand HS, Leigh JE, Rubin J, et al. Surgical adjuvant therapy of large-bowel carcinoma: an evaluation of levamisole and the combination of levamisole and fluorouracil. J Clin Oncol 1989;7:1447-56.

18. Holcombe RF, Stewart RM, Betzing KW, Kannan K. Alteration in lymphocyte phenotype associated with administration of adjuvant levamisole and 5fluorouracil. Cancer Immunol Immunother 1994;34:394-8.

19. DeBrander M, Vandebroek J, Wassenaar H, De Cree J, Braisier A, Demoen B, et al. Immunological alterations induced by adjuvant treatment of postoperative colon carcinoma Duke's B or C with levamisole in combination with 5-FU. Anticancer Res 1995;15:2271-7.

20. Janik J, Kopp WC, Smith JW, Longo DL, Alvord G, Sharfman WH, et al. Dose-related immunologic effects of levamisole in patients with cancer. J Clin Oncol 1993;11:125-35.

21. Ishizawa T, Fukushima N, Shibahara J, Masuda K, Tamura S, Aoki T, Hasegawa K, Beck Y, Fukayama M, Kokudo N. Real-time identification of liver cancers by using indocyanine green fluorescent imaging. Cancer. 2009 June 1; 115(11):2491-2504.

22. Holcombe RF, Milovanovic T, Stewart RM, Brodhag TM. Investigating the role of immunomodulation for colon cancer prevention: results of an in vivo dose escalation trial of levamisole with immunologic endpoints. Cancer Detect Prev. 2001;25(2):183-91.

23. Clarke GR, Burton RC, Smart YC. The antitumor effects of levamisole in mice are mediated by NC-1.1+ cells. Cancer Immunol Immunother. 1997 Oct;45(2):115-8.

24. de Waard JW, de Man BM, Wobbes T, van der Linden CJ, Hendriks T. Inhibition of fibroblast collagen synthesis and proliferation by levamisole and 5 -fluorouracil. Eur J Cancer 1998;34:162-7.

25. Nachbaur DM, Herold $M$, Maneschg A, Huber $H$. Serum levels of interleukin-6 in multiple myeloma and other hematological disorders: Correlation with disease activity and other prognostic parameters. Ann Hematol 1991;62:54-8.

26. Reittie JE, Yong KL, Panayiotidis $P$, Hoffbrand AV. Interleukin-6 inhibits apoptosis and tumour necrosis factor induced proliferation of B-chronic lymphocytic leukaemia. Leuk Lymphoma 1996;22:83-90.

27. Artwohl M, Hölzenbein T, Wagner L, Freudenthaler A, Waldhäusl W, BaumgartnerParzer SM. Levamisole induced apoptosis in cultured vascular endothelial cells. Br J Pharmacol 2000;131:1577-83. 
Levamisole in treatment of urethane-induced pulmonary carcinoma in rats

Silva ALC, et al

28. Marty LM, Feldbush TL. Effect of anti-alkaline phosphatase monoclonal antibody on B lymphocyte function. Immunol Lett 1993;38:87-95. 